Energy Research Journal 1 (1): 6-11, 2010

ISSN 1949-0151

(C) 2010 Science Publications

\title{
The Influence of Total Solid Contents on Biogas Yield from Cattle Manure Using Rumen Fluid Inoculum
}

\author{
${ }^{1,2}$ Budiyono, ${ }^{2}$ I.N. Widiasa, ${ }^{1}$ S. Johari and ${ }^{1}$ Sunarso \\ ${ }^{1}$ Diponegoro University, Jl. Imam Bardjo, SH No. 5 Semarang, Indonesia \\ ${ }^{2}$ Department of Chemical Engineering, Faculty of Engineering, Diponegoro University, \\ Jl. Prof. Sudarto, SH No. 1 Semarang, Indonesia
}

\begin{abstract}
Problem statement: Anaerobic digestion was a biological method used to convert organic wastes into biogas and a stable product for land application without adverse environmental effects. The biogas produced could be used as an alternative renewable energy source. The aim of this study was to analyze the influence of total solid contents on biogas yield from cattle manure using fluid rumen inoculums. Approach: A series of laboratory experiments using $400 \mathrm{~mL}$ biodigester were performed in batch operation mode. Given $100 \mathrm{~g}$ of fresh cattle manure was fed to each biodigester and mixed with fixed $50 \mathrm{~mL}$ of rumen fluid and different volumes of tap water resulting six different Total Solid (TS) contents i.e., 2.6, 4.6, 6.2, 7.4, 9.2, 12.3 and 18.4\%. Results: The results showed that the best performance for biogas production was the digester with 7.4 and $9.2 \%$ of total solid i.e., gave biogas yield 184.09 and $186.28 \mathrm{~mL} \mathrm{gVS}^{-1}$, respectively after 90 days observation. While the other TSs content of 2.6, 4.6, 6.2, 12.3 and $18.4 \%$ gave the biogas yield 115.78, 122.33, 172.34, 137.99 and $54.87 \mathrm{~mL} \mathrm{gVS}^{-1}$, respectively. Conclusion: These results suggested that, based on TS content effects to biogas yield, rumen fluid inoculum exhibit the similar effect with other inoculums. In all cases, there was no variation of $\mathrm{pH}$, fat, protein and ash content in sludge after digestion at several variation of $\mathrm{pH}$. During digesting, $\mathrm{pH}$ tends to increase to neutral $\mathrm{pH}$ i.e., optimum $\mathrm{pH}$ for methanogenic bacteria. The effect of rumen fluid concentration to biogas production will need to be studied in the next step research.
\end{abstract}

Key words: Rumen fluid, inoculums, biogas yield

\section{INTRODUCTION}

One of the most important challenges that our world will face in the twenty-first century will be continuing to meet the ever increasing energy needs of its citizen. Along with the need to find a renewable long term energy source is the need to find a more environmental friendly one. One of the promising candidates as a power source solution for the future world energy problem is biomass such as manure from animal agricultural waste (Nallathambi, 1997). Common terminology to describe the biological origin of a product includes terms such as biofuel, bioenergy and biogas. Anaerobic Digestion (AD) is a biological method used to convert organic wastes into biogas and a stable product for land application without adverse environmental effects. The biogas produced can be used as an alternative renewable energy source. AD that utilizes manure for biogas production is one of the most promising uses of biomass wastes because it provides a source of energy while simultaneously resolving ecological and agrochemical issues. The anaerobic fermentation of manure for biogas production does not reduce its value as a fertilizer supplement, as available nitrogen and other substances remain in the treated sludge (Alvarez and Liden, 2008).

The rate and efficiency of the anaerobic digestion process is controlled by the type of waste being digested, concentration, temperature, the presence of toxic materials, the $\mathrm{pH}$ and alkalinity, the Hydraulic Retention Time (HRT), the Solids Retention Time (SRT), the ratio of Food to Microorganisms (F/M ratio), the rate of digester loading and the rate at which toxic end products of digestion are removed (Burke, 2001). According to Sadaka and dan Engler (2003), water content is one of very important parameter affecting $\mathrm{AD}$ of solid wastes. There are two main reason i.e., (a) water make possible the movement and growth of bacteria facilitating the dissolution and transport of nutrient and (b) water reduces the limitation of mass transfer of non homogenous or particulate substrate. The $\mathrm{AD}$ process operate with high solid content will decrease 
Energy Rec. J. 1 (1): 6-11, 2010

digester volume because water need as solvent will also decrease. However, according to Muryanto et al. (2006) and Balsam (2002) the optimum solid content obtained for biogas production is in the range $7-9 \%$. Furthermore, according to Sadaka and dan Engler (2003), the higher solid content in feed will lessen cummulative biogas produced without depend on kinds of animal manure.

On the other hands, according to Budiyono et al. (2009) rumen fluid inoculated to biodigester gave significant effect to biogas production. Rumen fluid inoculums caused biogas production rate and efficiency increase two to three times in compare to manure substrate without rumen fluid. Similar with these results, several researchers reported that inoculums are substantially relevant in process kinetics of biogas production (Luengo and Alvarez, 1988); amount of methane produced seemed proportional to the initial cattle manure as inoculums (Castillo et al., 1995); a strong influence of the bovine rumen fluid inoculums on anaerobic biostabilization of fermentable organic fraction of municipal solid waste (Lopes et al., 2004) and the higher percentage of inoculums gave the higher production of biogas (Forster-Carneiro et al., 2008). However, almost all of $\mathrm{AD}$ studied before, inoculums used were dominated by digested sludge from anaerobic digester as well as animal manure. In addition, to our best knowledge, in point of view the using rumen fluid as inoculums; data concerning the study of the effect of TS content to biogas production rate from cattle manure are very limited. Hence, this study focuses on the use of rumen fluid as inoculums for biogas production from cattle manure in several TS content.

\section{MATERIALS AND METHODS}

Sample preparation: The cattle manures and rumen fluids used in this research were taken randomly from slaughterhouse located on Semarang city. The fresh raw manure was collected from animal holding pen unit while rumen was collected from evisceration unit. Rumen fluid was prepared as follows: Rumen content is poured to $100 \mathrm{~L}$ tank and added $25 \mathrm{~L}$ of tap water. Solid content then be separated from slurry by filter cloth. To assure that solid content in solution are dominated by bacteria, solution obtained then be filtered by 10 micron cartridge filter. Before using, all of raw manure collected is homogenized by mixing with propeller mixer. Raw manure and rumen fluid sample was analyzed its Dry Matter (DM) and Volatile Solid (VS) content by mean heating at 105 and $600^{\circ} \mathrm{C}$, respectively. DM and VS content of fresh cattle manure and rumen fluid are presented in Table 1.
Table 1: DM and VS characteristics of fresh cattle manure and rumen

\begin{tabular}{lll}
\multicolumn{1}{c}{ fluid } & & \\
\hline Parameter & Fresh manure & Rumen fluid \\
\hline $\mathrm{DM}(\%)$ & $18.40 \pm 0.65$ & $1.71 \pm 0.03$ \\
$\mathrm{VM}(\%)$ & $16.74 \pm 0.15$ & $1.50 \pm 0.01$ \\
\hline
\end{tabular}

Table 2: Composition of six manure samples used in the study

\begin{tabular}{lrlrl}
\hline TS $(\%)$ & VS $(\%)$ & Cattle manure $(\mathrm{g})$ & Water $(\mathrm{mL})$ & Rumen fluid $(\mathrm{mL})$ \\
\hline 2.64 & 2.31 & 100 & 550 & 50 \\
4.61 & 4.04 & 100 & 250 & 50 \\
6.15 & 5.38 & 100 & 150 & 50 \\
7.38 & 6.46 & 100 & 100 & 50 \\
9.23 & 8.07 & 100 & 50 & 50 \\
12.30 & 10.76 & 100 & 0 & 50 \\
18.40 & 16.74 & 100 & 0 & 0 \\
\hline
\end{tabular}

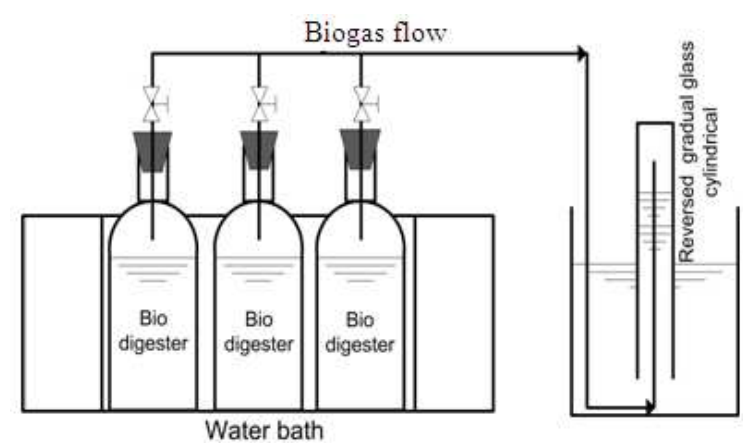

Fig. 1: Schematic diagram of series laboratory batch assessment of anaerobic digestion

Experimental apparatus set up: A series laboratory test of $400 \mathrm{~mL}$ biodigester was operated in batch system. The main experiment apparatus consists of biodigester and biogas measurement. Biodigester were made from polyethylene bottle plugged with tightly rubber plug and was equipped with valve for biogas measurement. Biogas formed was measured by 'liquid displacement method' as also has been used by Yetilmezsoy and Sakar (2008). The schematic diagram of experimental laboratory set up as depicted in Fig. 1.

Experimental design: The influence of Total Solid (TS) content to biogas production was studied by performing a series laboratory biodigester in several TS level in feed. A series of laboratory experiments using $400 \mathrm{~mL}$ biodigester were performed in batch operation mode. Given $100 \mathrm{~g}$ of fresh cattle manure was fed to each biodigester and mixed with fixed $50 \mathrm{~mL}$ of rumen fluid and different volumes of tap water resulting six different TS contents i.e., 2.64, $4.61,6.15,7.38,9.23,12.30$ and $18.40 \%$ (equivalent to Volatile Solid (VS) of 2.31, 4.4, 5.38, 6.46, 8.07, 10.76 and $16.74 \%$, respectively). Composition of six 
manure samples used in the study as presented in Table 2. Operating temperature was at room temperature. The biodigester performance was measured with respect to cumulative volume of biogas produced after corrected to standard pressure $(760 \mathrm{~mm}$ $\mathrm{Hg}$ ) and temperature $0^{\circ} \mathrm{C}$. All of treatment was carried out by triplication.

Experimental procedures: The manure sample with certain TS content as research variables was fed to biodigester and homogenized with mixer propeller. $\mathrm{CO}_{2}$ gas was bubbled to biodigester to assure that biodigester in anaerobic condition. Biogas formed was measured every two days and stopped after biogas was insignificantly produced. The similar procedure was performed in three replications. Significance difference between treatments was determined statistically by Duncan Multiple Range Test (DMRT).

\section{RESULTS}

Effect of Total Solid (TS) content to biogas production: The effect of TS content to biogas production was studied by varying TS from 2.64$18.40 \%$. The TS content was presented in term of Dry Matter (DM). The research was carried out in triplication. The data obtained from the study then is

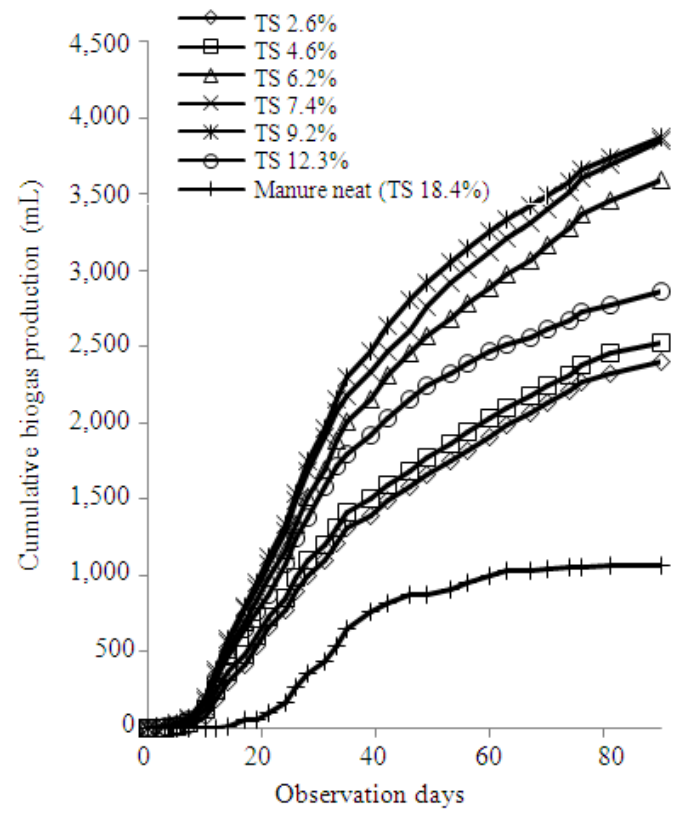

(a) averaged and the cumulative volume of biogas production was observed during 90 days as depicted in Fig. 2a. In other term, the cumulative biogas production per total VS added (specific biogas production) is presented in Fig. 2b. Numerical values of biogas yield in several days observation time is presented in Table 3.

Effect of TS content to performance of biodigester: Table 4 shows a summary of performance data at the end of the process for TSs content studied. Correspond to biogas yield, based on TS content, the TSs content of 7.4 and $9.2 \%$ exhibit the best performance for digestibility i.e., give digestibility 184.09 and $186.28 \mathrm{~mL} \mathrm{gVS}^{-1}$, respectively after 90 days observation. While the other TSs content of 2.6, 4.6, 6.2, 12.3 and $18.4 \%$ give the biogas yield $115.78,122.33$, $172.34,137.99,54.87 \mathrm{~mL} \mathrm{gVS}^{-1}$, respectively.

Table 3: Biogas yield in several days observation time

\begin{tabular}{|c|c|c|c|c|c|c|c|}
\hline \multirow{2}{*}{$\begin{array}{l}\text { Observation } \\
\text { Time (days) }\end{array}$} & \multicolumn{7}{|l|}{ TS (\%) } \\
\hline & 2.6 & 4.6 & 6.2 & 7.4 & 9.2 & 12.3 & 18.4 \\
\hline 0 & 0.00 & 0.00 & 0.00 & 0.00 & 0.00 & 0.00 & 0.00 \\
\hline 10 & 4.00 & 6.00 & 8.00 & 9.00 & 10.00 & 9.00 & 0.00 \\
\hline 20 & 33.00 & 36.00 & 49.00 & 54.00 & 56.00 & 44.00 & 5.00 \\
\hline 40 & 70.00 & 75.00 & 108.00 & 116.00 & 123.00 & 96.00 & 39.00 \\
\hline 60 & 95.00 & 101.00 & 144.00 & 156.00 & 162.00 & 123.00 & 51.00 \\
\hline 80 & 115.78 & 122.33 & 172.34 & 184.09 & 186.28 & 137.99 & 54.77 \\
\hline
\end{tabular}

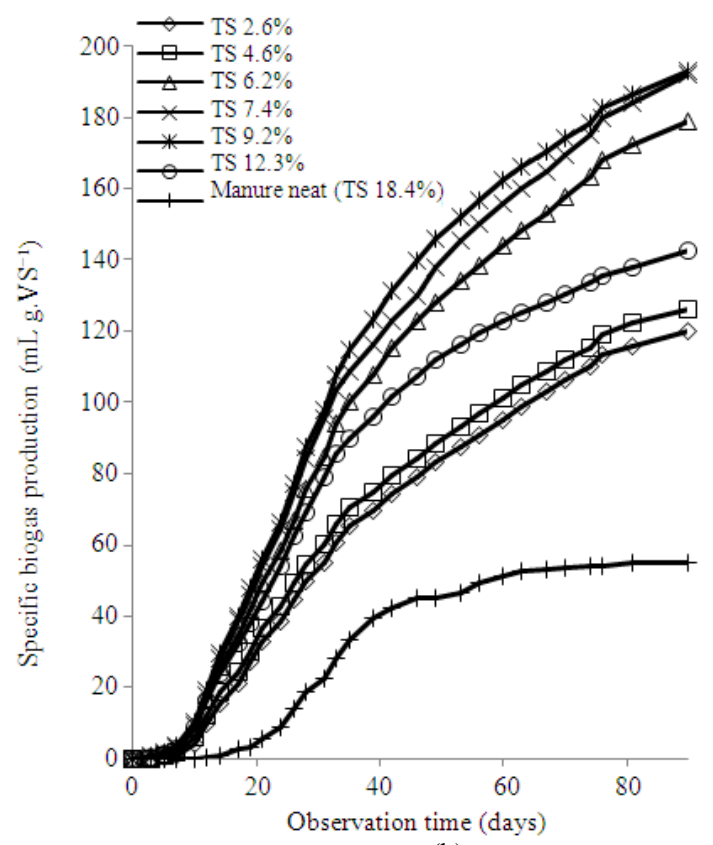

(b)

Fig. 2: The effect of TS content to biogas production 
Energy Rec. J. 1 (1): 6-11, 2010

Table 4: Results of 90 day batch anaerobic digestion of cattle manure in several TS content

\begin{tabular}{|c|c|c|c|c|c|c|c|c|c|}
\hline \multirow[b]{2}{*}{ No. } & \multirow[b]{2}{*}{ TS (\%) } & \multicolumn{5}{|c|}{ Sludge composition (\%) } & \multirow[b]{2}{*}{ Digest. DM (\%) } & \multicolumn{2}{|l|}{$\mathrm{pH}$} \\
\hline & & Water & TS (DM) & Fat (DM) & Protein DM & Ash (DM) & & Initial & Final \\
\hline$\overline{1}$ & 2.64 & 97.72 & 2.28 & 1.08 & 2.53 & 5.95 & 28.87 & 6.62 & 6.74 \\
\hline 2 & 4.61 & 96.21 & 3.79 & 0.93 & 1.83 & 6.32 & 31.11 & 6.48 & 6.70 \\
\hline 3 & 6.15 & 95.74 & 4.26 & 0.78 & 1.72 & 4.23 & 41.67 & 6.37 & 6.76 \\
\hline 4 & 7.38 & 95.13 & 4.87 & 1.02 & 1.67 & 7.88 & 44.66 & 6.34 & 6.78 \\
\hline 5 & 9.23 & 92.91 & 7.09 & 1.09 & 1.78 & 6.53 & 35.54 & 6.41 & 6.88 \\
\hline 6 & 12.30 & 89.21 & 10.79 & 0.63 & 2.21 & 4.84 & 26.45 & 6.45 & 6.97 \\
\hline
\end{tabular}

Note: Initial raw manure composition: DM 18.4\%; Ash 19.34 \% DM; Raw protein 9.03\% DM; Lipid 1.28\% DM; raw fiber 42.57\% DM

\section{DISCUSSION}

Figure 2 shows that, in general, biogas production rate tend to obey sigmoid function ( $\mathrm{S}$ curve) as generally occurred in batch growth curve and as also has be resulted by Budiyono et al. (2009). Biogas production is very slow at the beginning and the end period of observation.

This is predicted due to the biogas production rate in batch condition is directly corresponds to specific growth rate of methanogenic bacteria in the biodigester (Nopharatana et al., 2007). In the around of the first 10 days observation, biogas production is very low or indeed do not formed yet due to the lag phase of microbial growth. In the range of 10-50 days observation, biogas production is sigificantly increase due to exponential growth of microorganisms. After 50 days observation, biogas production tend to decrease and this is predicted tend due to stationary phase of microbial growth (Castillo et al., 1995).

From Fig. 2a and b also can be seen that after 90 days observation still there is the tendency to increase biogas production and don't stop yet. This is predicted that the carbons contained by all of waste constituents are not equally degraded or converted to biogas through anaerobic digestion. According to Richard (1996) and Wilkie (2005), anaerobic bacteria do not or very slow degrade lignin and some other hydrocarbons. In other word, the higher lignin content will lower biodegradability of waste. Animal manure such as waste used in this study include lignocellulosic rich materials, so anaerobically degradation also rather unoptimum (Nielsen and Angelidaki, 2008). Even, AD of cattle manure will cease completely after 360 days observation.

Furthermore, as shown in Fig. 2, the best performance for biogas production was the digester with 7.4 and $9.2 \%$ of TS i.e., give biogas yield 184.09 and $186.28 \mathrm{~mL} \mathrm{gVS}^{-1}$, respectively after 90 days observation. While the other TSs content of 2.6, 4.6, $6.2,12.3$ and $18.4 \%$ give the biogas yield 115.78 , 122.33, 172.34, 137.99, $54.87 \mathrm{~mL} \mathrm{gVS}^{-1}$, respectively. In addition, in the range of all of the observation time, TS contents of 7.4 and $9.2 \%$ are also exhibit the best performance in biogas yield as presented in Table 3. These results suggest that, based on TS content effects to biogas yield, rumen fluid inoculum exhibit the similar behavior with other inoculums, respectively. This is similar with the information from Balsam (2002) and Zennaki et al. (1996) that the optimum solid content obtained for biogas production is in the range 79\%. Furthermore, Baserja (1984) reported that the process was unstable below a total solids level of $7 \%$ (of manure) while a level of $10 \%$ caused an overloading of the fermenter. These results suggest that, based on TS content effects to biogas yield, rumen fluid inoculum exhibit the similar effect with other inoculums.

These results is predicted due the function of water in biodigester since the TS content will be directly correspond to water content. According to Sadaka and dan Engler (2003), water content is one of very important parameter affecting $\mathrm{AD}$ of solid wastes. There are two main reason i.e., (a) Water make possible the movement and growth of bacteria facilitating the dissolution and transport of nutrient and (b) water reduces the limitation of mass transfer of non homogenous or particulate substrate. Mathematically, the function of water in $\mathrm{AD}$ processes organic wastes consists of elements of Carbon (C), Hydrogen (H) and Oxyigen (O) reflected by reaction as follows (Buswell and Mueller, 1952; Speece, 1996):

$$
\begin{aligned}
& \mathrm{C}_{\mathrm{c}} \mathrm{H}_{\mathrm{h}} \mathrm{O}_{\mathrm{o}}+\left\lceil\frac{4 \mathrm{c}-\mathrm{h}-2 \mathrm{o}}{4}\right\rceil \mathrm{H}_{2} \mathrm{O}=====>\left\lceil\frac{4 \mathrm{c}-\mathrm{h}-2 \mathrm{o}}{8}\right\rceil \\
& \mathrm{CH}_{4}+\left\lfloor\frac{4 \mathrm{c}-\mathrm{h}-2 \mathrm{o}}{8}\right\rfloor \mathrm{CO}_{2}
\end{aligned}
$$

Furthermore, the water needed for biogas production from organic wastes consists of elements of Carbon (C), Hydrogen $(\mathrm{H})$ and Oxyigen (O) and Nitrogen $(\mathrm{N})$ is reflected by reaction as follows (Gelegenis et al., 2007):

$$
\begin{aligned}
& \mathrm{C}_{\mathrm{c}} \mathrm{H}_{\mathrm{h}} \mathrm{O}_{\mathrm{o}} \mathrm{N}_{\mathrm{n}}+\left\lceil\frac{4 \mathrm{c}-\mathrm{h}-2 \mathrm{o}+3 \mathrm{n}}{4}\right\rceil \mathrm{H}_{2} \mathrm{O}===== \\
& \left\lceil\frac{4 \mathrm{c}+\mathrm{h}-2 \mathrm{o}-3 \mathrm{n}}{8}\right\rceil \mathrm{CH}_{4}+\left\lfloor\frac{4 \mathrm{c}-\mathrm{h}+2 \mathrm{o}+3 \mathrm{n}}{8}\right\rfloor \mathrm{CO}_{2}+\mathrm{nNH}_{3}
\end{aligned}
$$


The both two above equation depicted how important the water need in $\mathrm{AD}$ process for biogas production. Finally, the most important finding of this research that that the best performance for biogas production was the digester with $7-9 \%$ of TS similar with conventional processes used other inoculums. However, although the same optimum concentration of TS, rumen fluid inoculums caused biogas production rate and efficiency increase two to three times in compare to manure substrate without rumen fluid, as has been stated by Budiyono et al. (2009).

Table 4 also shows that, in all cases, there is an increase of $\mathrm{pH}$ before and after digestion. Before digestion, $\mathrm{pH}$ varies from 6.37-6.62 while after digestion $\mathrm{pH}$ varies from 6.70-6.97. The increase of $\mathrm{pH}$ is predicted due to degradation of protein to give ammonia (Eq. 2). The final pH 6.70-6.97 indicate that the high crude protein in cattle manure (in this case $9.03 \%$ ) give the benefit effect for bringing $\mathrm{pH}$ toward the neutral $\mathrm{pH}$ i.e., optimum $\mathrm{pH}$ for methanogenic bacteria is 6.8-7.2 (Rajeshwari et al., 2000).

In addition, no significant variation of sludge protein content in all of variation of TS content. Crude protein varies between $1.67-2.53 \%$. This result indicates that anaerobic sludge from all of TS variation still have benefit for being used as liquid fertilizer. Over all, there is no variation of fat, protein and ash content in sludge after digestion. These results suggest that in point of view of fat, protein and ash content, all of substrate has been degraded to biogas in the relatively same rate. Finally, the conclusion can be drawn that variation of TS content will give the significant effect to digestibility of TS content to be produced as biogas.

\section{CONCLUSION}

The effect of water and solid content to biogas production was studied by performing a series laboratory experiment using rumen fluid of animal ruminant as inoculums. The most important finding from this research is that the best performance for biogas generation was the digester with 7.4 and $9.2 \%$ of total solid i.e., give biogas yield 184.09 and $186.28 \mathrm{~mL} \mathrm{gVS}^{-1}$, respectively after 80 days observation. These results suggest that, based on TS content effects to biogas yield, rumen fluid inoculum exhibit the similar effect with other inoculums.

In all cases, there is no variation of $\mathrm{pH}$, fat, protein and ash content in sludge after digestion at several variation of $\mathrm{pH}$. During digesting, high crude protein in cattle tend to give the benefit effect for bringing $\mathrm{pH}$ toward the neutral $\mathrm{pH}$ i.e., optimum $\mathrm{pH}$ for methanogenic bacteria is 6.8-7.2. In addition, there is no significant variation of sludge protein content in all of variation of TS content. Crude protein varies between $1.67-2.53 \%$. This result indicates that anaerobic sludge from all of TS variation still has the potential benefit for being used as liquid fertilizer.

The effec of rumen fluid concentration to biogas production will need to be studied in the next step research. In addition, the future research will be carried out to study the dynamics of biogas production if both the rumen inoculums and manure are fed in the continuous system.

\section{ACKNOWLEDGEMENT}

We gratefully acknowledge to the Higher Education Directorate, National Education Department and Republic of Indonesia due to the support to this research via the Hibah Doktor (Ph.D. Grant).

\section{REFERENCES}

Alvarez, R. and G. Liden, 2008. The effect of temperature variation on biomethanation at high altitude. Biores. Technol., 99: 7278-7284. DOI: 10.1016/j.biortech.2007.12.055

Balsam, J., 2002. Anaerobic digestion of animal wastes: Factors to consider. ATTRA-national sustainable agriculture information service. United States Department of Agriculture's, USA. http://www.attra.ncat.org

Baserja, U., 1984. Biogas production from cowdung: Influence of time and fresh liquid manure. SwissBio Tech., 2: 19-24.

Budiyono, I.N. Widiasa, S. Johari and Sunarso, 2009. Biogas Production Kinetic from Cow Manure using Liquid Rumen As Inoculum, Proceeding of the Seminar National Teknik Kimia Indonesia, (SNTKI'09), Bandung, pp: ETU-10.

Burke, D.A., 2001. Dairy Waste Anaerobic Digestion Handbook. Environmental Energy Company, 6007 Hill Street Olympia, WA 98516, pp: 17-27.

Buswell, A.M. and H.F. Mueller, 1952. Mechanism of methane fermentation. Ind. Eng. Chem., 44: 550-552.

Castillo, R.T., P.L. Luengo and J.M. Alvarez, 1995. Temperature effect on anaerobic of bedding manure in a one phase system at different inoculums concentration. Agric. Ecosyst. Environ., 54: 55-66. DOI: 10.1016/0167-8809(95)00592-G

Forster-Carneiro, T., M. Pérez and L.I. Romero, 2008. Influence of total solid and inoculum contents on performance of anaerobic reactors treating food waste. Bioresour. Technol., 99: 6994-7002. DOI: 10.1016/j.biortech.2008.01.018 
Gelegenis, J., D. Georgakakis, I. Angelidaki and V. Mavris, 2007. Optimization of biogas production by co-digesting whey with diluted poultry manure. Renew. Energy, 32: 2147-2160. DOI: 10.1016/j.apenergy.2006.12.001

Lopes, W.S., V.D. Leite and S. Prasad, 2004. Influence of inoculum on performance of anaerobic reactors for treating municipal solid waste. Bioresour. Technol., 94: 261-266. DOI: 10.1016/j.biortech.2004.01.006

Luengo, P.L. and J.M. Alvarez, 1988. Influence of temperature, buffer, composition and straw particle length on the anaerobic digestion of wheat strawpig manure mixtures. Resour. Conserv. Recycl., 1: 27-37. DOI: 10.1016/09213449(88)90005-5

Muryanto, J.P., K.E. Suprapto and D. Sudadiyono, 2006. Biogas, Alternative Energy Ramah Lingkungan. Print 1, Research Centre of Agricultural Technology (BPTP), Jawa Tengah, ISBN: 979-9007-32-1, pp: 22

Nallathambi, G.V., 1997. Anaerobic digestion of biomass for methane production: A review. Biomass Bioenergy, 13: 83-114. DOI: 10.1016/S0961-9534(97)00020-2

Nielsen, H.B. and I. Angelidaki, 2008. Strategies for optimizing recovery of the biogas process following ammonia inhibition. Bioresour. Technol., 99: 7995-8001. DOI: 10.1016/j.biortech.2008.03.049

Nopharatana, A., P.C. Pullammanappallil and W.P. Clarke, 2007. Kinetics and dynamic modeling of batch anaerobic digestion of municipal solid waste in a stirred reactor. Waste Manage., 27: 595-603. DOI: 10.1016/j.wasman.2006.04.010
Rajeshwari, K.V., M. Balakrishnan, A. Kansal, K. Lata and V.V.N. Kishore, 2000. State-of-the-art of anaerobic digestion technology for industrial wastewater treatment. Renew. Sustain. Energy Rev., 4: 135-156. DOI: 10.1016/S13640321(99)00014-3

Richard, T., 1996. The effect of lignin on biodegradability. Cornell Composting, Cornel Waste Management Institute. http://www.cfe.cornell.edu/compost/calc/lignin.ht $\mathrm{ml}$

Sadaka, S.S. and C.R. dan Engler, 2003. Effect of initial total solids on composting of raw manure with biogas recovery. Compost Sci. Utilizat., 11: 361-369.

Speece, R.E., 1996. Anaerobic Technology for Industrial Wastewaters. Archae Press, USA., ISBN: 0-9650226-0-9, pp: 22.

Wilkie, A.C., 2005. Anaerobic Digestion of Dairy Manure: Design and Process Consideration. In: Dairy Manure Management: Treatments, Handling, and Community Relations, Natural Resource, Agriculture, and Engineering Service, Cornell University, Itaca, pp: 301-312.

Yetilmezsoy, K. and S. Sakar, 2008. Development of empirical models for performance evaluation of UASB reactors treating poultry manure wastewater under different operational conditions, J. Hazardous Materials, 153: 532-543. DOI: 10.1016/j.jhazmat.2007.08.087

Zennaki, B.Z., A. Zadi, H. Lamini, M. Aubinear and M. Boulif, 1996. Methane Fermentation of cattle manure: Effects of HRT, temperature and substrate concentration. Tropicutural, 14: 134-140. 